\title{
China and India in Eurasia: A Strategic Analysis
}

\author{
Haoqing Zhu ${ }^{1, *}$
}

\author{
${ }^{1}$ University of California, Irvine \\ *Email:Haoqiz3@uci.edu
}

\begin{abstract}
The concept of Eurasia is connectivity between Europe and Asia. For the past decades, Eurasia has been redefined by two powerful countries China and India. China has designed its foreign policy to focus on establishing economic and cultural relationships with countries in Eurasia. China's important initiatives are "The New Silk Road" (also known as "One Belt One Road") and Maritime Silk Road. On the other hand, India has not yet seen a clear grand strategy in Eurasia at this moment. However, the Indian government shows a defensive tendency in the Indian Ocean in response to China's Marine time Silk Road policy and wants to cooperate sustainable investment with China. China and India have a matured nuclear arsenal from a nuclear approach and have been accustomed to minimizing nuclear deterrence. In recent years, China has a predominant military and economic advantage over India from nuclear weapon development and international trade perspectives. However, India owes a geographical advantage and multinational support; China needs to be concerned about its further maritime silk road development potential military collision. The oath of cooperation between two Asia superpowers becomes a blur and remains controversial.
\end{abstract}

\section{Keywords: The New Silk Road, One Belt One Road, China, India, Geopolitics in Asia, China Grand Strategy, India Grand Strategy, Nuclear deterrence}

\section{INTRODUCTION}

China's growth of national power in present days correlates with the major dialogue of international relations. India, meanwhile, views China as a threat to multilateral conventions. Both China and India represent two growing powers that can penetrate global west dominance in the world order. As a result, it is categorical to investigate the relationship between these two countries. They address the grand strategic plan and military operation since these two factors can facilitate understanding transitory and long-term national diplomatic arrangements. However, recent studies on analyzing China and India are biased with limited resources about China's initial governance plan toward Eurasia, as same as India. This paper aims to provide a comprehensive overview of India's and China's grand strategies in Eurasia and how they operate and investigate each country's strengths and weaknesses. Lastly, we will also discuss China and India's economic and nuclear approach in Eurasia from a geopolitical perspective.

\section{CHINA GRAND STRATEGY IN EURASIA}

China, a considerable rising great power, has become the largest manufacturing country globally and is actively seeking its role in innovating and cooperating with countries across Eurasia. To operate its progressive plan, Beijing framed a grand strategy. Before we divide the actual plan and policy portion of China's grand strategy, we need to acknowledge the impetus of why China is steadily making progress along with its international success. A great power's grand strategy is "often intertwined with a state's perceived or actual rivalry with another state." [1]. In Beijing's perception, the rivalry is the United States of America. Since the China Civil War, when Americans funded artilleries and training for the Republic of China (Taiwan) that is the enemy of the Chinese Communist Party, the People's Republic of China (PRC) has nurtured an unhostile relationship with the U.S. When moving into the modern era, PRC underwent several embargoes that Trump's administration imposes. Consequently, these actions have led to an economic rivalry between PRC and the USA. In response to the U.S., China confronts "a hard power threat in the form of economic heft" [1] and "a soft power threat in the form of subversive U.S. concepts 
about individual freedoms." [1] Naturally, Beijing is looking to relocate the economic cooperation from the U.S. to Eurasia and attempting the "one mega-foreign policy project" that is known as the New Silk Road Project [2].

The New Silk Road Project (also named One Belt One Road) is a multidimensional infrastructure development initiative reached from China to Europe and Africa continent by constructing "high-speed rail, roads, ports, internet networks, and fiber optic cables." [2]. The project has been developed from land and sea. President Xi Jinping's ambition is to use the "New Silk Road Project" to connect China with Europe that is also considered as a key part of "China's Greater Neighborhood Policy (GNP)" [3]. Infrastructure building is one of the "soft power" and diplomatic strategy by PRC for the creation of a long trajected impact on the Eurasia region. Moreover, China is building an international trade network that could create wealth for all countries in the initiative. According to a news report published by China Pictorial in 2019, Zhai Huixia illustrated that the total volume of foreign trade imports and exports between China and countries along the Belt Road Initiative was " 8.3 trillion yuan (1.27 trillion USD), a year-on-year increase of $13.3 \%$, and 17 free trade agreements were reached with 25 countries and regions." [4] Sharing mutual benefits is evident. Major highincome countries in Eurasia include Turkey, Iran, and Singapore. South Korea, Poland, and Russia are all involved in BRI. Not only has Beijing presented its hostility by funding and building transportation for countries in BRI. Xi Jinping also has an ambitious vision to reform the Chinese economy basis from manufacturing to self-innovation. Operating Free Trade Zones (FTZ) are tax-friendly to foreign goods and domestic products and "healthier currency flows" that attract global investments [5]. Under a flexible and liberal foreign exchange policy, FTZ brings opportunities for countries in the BRI to expand their business operations in China. In depth, the New Silk Road Project could be viewed as an offensive and defensive strategy from Beijing's response to Washington. As previously motioned, though the U.S. is also part of "China's greater neighborhood across the pacific", China orients the BRI in Eurasia and tacitly excludes the United States [3].

After addressing the economic achievement of the Belt Road Initiative, Beijing also dedicates to create a Maritime Silk Road that (String of Pearls) intends to connect Southeast Asia with Middle East, Europe, and North Africa through the Indian Ocean. The strategic plan has received many backlashes from India that resists cooperating with China by any means. Perhaps, India's aversion to Chinese economic cooperation is reasonable after viewing China-Pakistan Relationship. Pakistan remains hostile with India since 1965 [6]. In recent years, China has invested largely in Pakistan and established a well-developed bilateral national relationship. ChinaPakistan Economic Corridor (CPEC) is a China strategic plan specially designed for Pakistan to aid its expansion of BRI. The plan aims to develop and build "ports, transportation routes, power stations and other infrastructure" [6] to facilitate Pakistan's national development. Essentially, Gwadar port is the primary focus of the CPEC. Geographically, Gwadar port is vitally crucial for China on both BRI and Maritime Silk Road route development. In figure 1, the location of Gwadar port creates a well-secured trade route that allows China to connect with the Middle East in both the railway system and sea shipping. On the other hand, Gwadar can also impose a direct military threat to India that "extends its presence in the Indian Ocean and the Arabian Sea." [7]. Worth of mention, the term "pearls" refers to an individual port project. It can "create a chain of hubs, serving as economic centers or military and surveillance outposts for the Chinese army" [10]. 


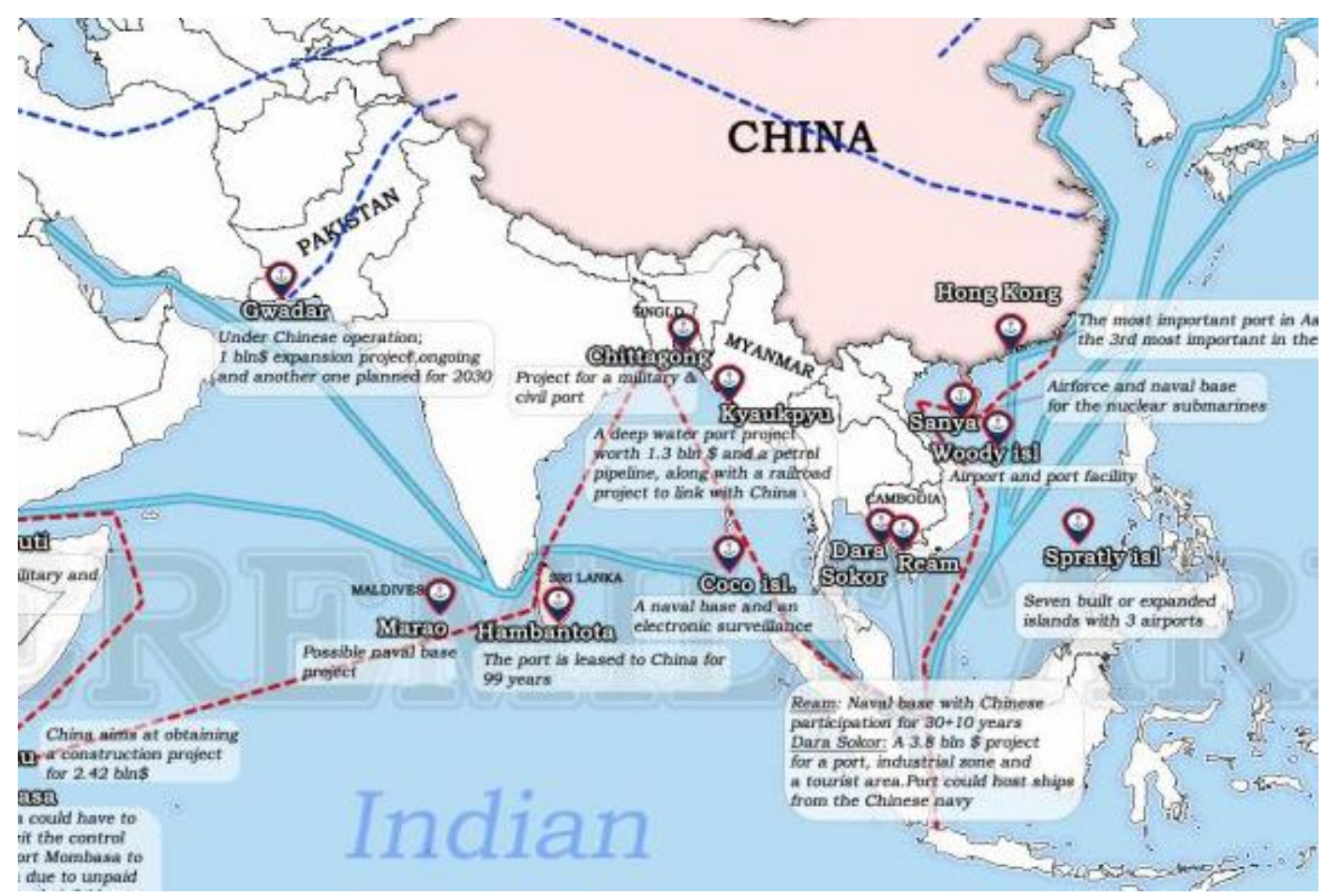

Figure 1. The location of Gwadar port in New Silk Road Project

As several resources stated, China and Pakistan are building "a new high-security compound" and potentially deploying marine forces in Gwadar, which raises high attention from India [8]. As a return, the Pakistan army is now equipped with China that provided "advanced artilleries and annually military training" that strengthens national military power and raises concerns by India [7]. Under the unsettled diplomatic and border conflict with India, China-Pakistan Relationship is essential for China's grand strategy development in Eurasia. CPEC has enhanced the Belt and Road Initiative and depicted a powerful impact on the Maritime Silk Road security.

In general, Beijing launches a soft power that is concentrated on grand strategy in Eurasia. The New Silk Road Project lays a foundation for China's foreign policy, beyond the implication of infrastructure development. It has a deep influence on forming a nexus in the economic, military, and cultural fields. When China distributes "COVID vaccines to emerging or lowincome countries to advance their interests", we can witness the tendency of beyond business relationship by China during the COVID-19 pandemic [9]. By doing so, China successfully promotes its reliability of innovation and earns its credibility by assisting BRI countries in recovering from the pandemic. China's ambition is to organize a political alliance in Eurasia without U.S. interference and eventually form its economy. However, India intrudes on the blueprint of China's grand strategy, which will be discussed next.

\section{INDIA GRAND STRATEGY IN EURASIA}

Now, India is at a strategic critical point and has several objectives to concern. First of all, India's rejection of BRI has placed itself into a confrontation with China in the Indian Ocean. Secondly, China-India skirmishes may lead to a serious consequence to the shape of India's Grand Strategy in Eurasia. The primary understanding of India's grand strategy is to respond to the BRI and continuous incentives from China and Pakistan. From New Delhi's vision, BRI contradicts Indian strategic and economic interests that can be explained by CPEC operation in territory claimed by India. Thirdly, India prime minister Narendra Modi worries that the BRI will likely "draw India into a relationship of dependency that China will be able to exploit" and jeopardize the cooperative relationship with the United States [11].

After the independence declaration from British colonial ruling, India's general approach to the world was to avoid "proximity to the global sources of economic and political power" [12]. This approach has changed in recent years by Narendra Modi. The rise of China challenged India's national power in Southeast Asia. Most importantly, BRI's maritime plan, namely String of Pearls, activates an indirect strategic target against India's sovereignty in the Indian Ocean. In depth, Gwadar port, the outcome of CPEC, is equipped with military compounds, making a direct threat to the northern coastline of India. Indeed, the string of pearls covers "the important chokepoints including Strait of Mandeb, Strait of Malacca, the Strait of Hormuz and the Lombok Strait."[13]. In short, India is isolated and surrounded by deployments of the People's Liberation Army Navy (PLAN). To avoid falling into the dilemma from strings of pearls, India responses from multiple 
approaches. Firstly, India is also expanding its strategic influence by building ports and providing military support in Eurasia. India, Iran, and Afghanistan signed a transnational agreement to develop Iran's southern port of Chabahar in 2016 [14]. Investing in Chabahar grants India access to "Afghanistan and other Middle East countries by avoiding Pakistan using land and air space to links itself to these newly emerging resource-rich countries" and global markets [13]. The 500 million dollars deal of developing Chabahar Port is designed to "compete with Gwadar Port and BRI." [14].

Since 1976, India has also remained a strong military tie with the Maldives. In 1988, India supported the Maldives government "with 1600 military forces for repelling a group of invading militants." [13]. As a friend to India, Maldives has always committed to perceiving its obligation. For this reason, Maldives has not yet joined BRI and patched up a defense cooperation plan with India in 2016. Similarly, India has also established an economic and military bilateral agreement with Sri Lanka. The success of the Indo-Sri Lanka relationship is large because of the Rani Wickremasinghe pro-India government that re-examines the partnership with China [13]. In 2016, India and Sri Lanka signed a plan to build Trincomalee Port to "counter Chinese supported Hambantota Port" [15]

Being strategically important to China, Myanmar is a critical location to India. To India, Myanmar is the only country that "shares both land and maritime border with India." [13]. As for China, Myanmar can propose a direct threat to India from the southern border. Simultaneously, Beijing and New Deli are both heavily investing in Myanmar. As part of BRI, PRC has built "Port Kyaukphyu, special economic zone, and oil and gas pipeline." [16]. On the other hand, India decided to strengthen its military ties with India by providing weapons and training to Myanmar National Army Force [13].

The Sino-India diplomatic conflicts occur in Myanmar, Sri Lanka, and the Maldives. India actively reinforces its international influence from Asian countries that are also politically against China and seeking western democracy's support. Both actions are considered as the second approach of response by India. Beginning with India's relationship with Vietnam, Indian Prime Minister Modi announced "a 500-million-dollar line of credit for Vietnam to facilitate deeper defense cooperation" and "a further 5 million dollars were granted for setting up Software Park in the country." [17]. Since China and Vietnam clash over territorial water disputes in the South China Sea, India's economic investment in Vietnam implies China's inability in a disguised form. On the other hand, India has joined the Quadrilateral Initiative (Quad), a formal security dialogue among India, Japan, the United States, and Australia. In recent years, the main topic for Quad is centered on China's Maritime Silk Road (MSR) Initiative and offers unique concerns to all [18]. Allied with India, Japan concerns that the MSR initiative would block its energy transportation from Middle East countries. A total of $90 \%$ of Japan's energy is imported from Middle East countries [18]. From Australia's and the United States perspectives, both countries lie outside the trade route of the New Silk Road Project, but both regard China as a security and economic threat. The United States claimed not to intervene in the Sino-India region conflict. At the same time, it has led to the Transpacific Partnership (TPP) formation to limit the attractiveness of Chinese economic expansion [18]. The United States and India have also expanded their security and defended cooperation by organizing joint exercises and exchanges [19]. As a result, New Delhi defends itself by pulling western alliances into the competition against China. Even though the United States stated to not heavily intercede in China's BRI, Japan has shown some degrees of support by exporting 12 maritime advances, Shin Maya, US 2 Ambitious Aircraft by 13 billion dollars [13]. India's intention is clear. It wants to apply the U.S.dominated powerhouse to offer pressure to China and protect its sovereignty in Eurasia.

\section{SINO-INDIA GRAND STRATEGY COMPARISON}

In summary, India and China are deeply intertwined in resource competition in Eurasia. However, the power dynamic between the two countries on placing strategic plans remains unbalanced. India's grand strategy that can be described as responsive actions to BRI, is passive compared with China's grand strategy.

Regardless of India's reaction, Beijing presents a clear economic approach to Eurasia in BRI. In BRI grand strategy proposed five visions, namely "Policy Communication", "People to people", "Facility Connectivity", "Financial Intermediation", "Unimpeded Trade". Out of the five visions, two are economic prospects. Financial intermediation is mainly implied to "China's internationalization of its currency (Renminbi) through BRI." [3]. Unimpeded trade is broadly described as expanding various investments to revolutionize the global market into the eco-friendly model. As BRI is continuing to develop in Central Asia and the Middle East, western scholars are often criticizing PRC's intention of loaning debt traps to low-income countries that can barely repay in a short time. Such an accusation is not substantially true. Multination research in 2019 was led by Roland Rajah, Alexandre Dayant, and Jonathan Pryke, who claimed: "as the nominal GDP of the region often grows much higher than the $2 \%$ interest charged, even the slow-growing Pacific economies may get rid of China's debt." [20]. However, to achieve its grand economic strategy, there also exist challenges to China. The primary ongoing concern to China is the financial 
outcome in the post-pandemic era. Due to the economic recession lead by the global pandemic in 2020, the risk of investment along countries in Eurasia escalates at a warning rate. Especially in Kyrgyzstan, Pakistan, Ukraine, Iran, and other Southeast Asia countries, the outbreak of COVID-19 has not effectively controlled among these countries that increase overall difficulties of trade [21]. By contrast, Beijing views the challenge less as a burden and much more as an opportunity. At the latest BRI International Cooperation Summit held in December 2020, committee members expressed that China now has a historical opportunity for BRI development during post-pandemic time with its "domestic and international dual cycle" economic plan [21]. In the 2020 new strategy in BRI, China is mainly focused on creating multilateral business cooperation with various countries. President Xi Jinping particularly mentions the necessity of helping BRI align countries with recovering and growing from financial stagnant even more, to expand cooperation in the fields of $5 \mathrm{G}$, smart cities, and big data technology applications [21].

Apart from mapping a substantial economic strategy, China also displays its advantages in military development to protect its alignments. In 2019, the Chinese government reported a defense expenditure budget of 178 billion dollars, while India spent 71.1 billion dollars in the same year [22]. Also, Chinese total available manpower fitted for military services can maximize around 6 million soldiers while India owns 4 million [23]. Sino-India conflicts in Indian Ocean regions (IOR) are not leveraged at all costs to India. PLANs are largely distributed in Hainan Island and Gwadar port to cause official concerns from New Deli. However, India has a natural geographical advantage in IOR that can enhance its impactful military presence. To explain more, PLANs are currently settled in Hainan Island as an important maritime military supply base. The distance to intervene in IOR and Malacca Strait is relatively longer than Indian naval forces. Considering Indian military force capacities, India has rapidly increased its military expenditure on purchasing advanced weapons from the United States, Israel, Russia, and Japan [23]. The case is different from China because the majority of Chinese military equipment is self-innovated and self-produced.

With its internal political conflicts, India's challenge is deeply rooted that negatively discharges its national power. Both ethnic conflict and government corruption result in a radical social view in the Indian public. Three ethnic conflicts have stood out of late: "Assam, Punjab and Hindu-Muslim conflict." [24]. Assam problem is primarily ethnic, and Punjab and Hindu-Muslim conflicts are predominantly religious conflicts. Out of all three conflicts, Assam has attracted the biggest attention from both home and abroad. Assam has the largest population growth in the past decades with the flood of migration from other areas of India. A high peasant-populated group mostly includes Bengali Muslims settled in Assam, and the class conflict between Bengali Muslims and Assamese middle class emerged. The results are that many people have been killed and uprooted as ethnic violence [24]. The hindu-Muslim conflict reflects the tension between Pakistan, a Muslim sovereign state, and India, a Hindu populated state. Interestingly, many Muslims did not migrate to Pakistan and choose to stay in India. The discrimination towards Muslims in India begins to exacerbate and penetrate "the character of electoral politics" [24]. The unsettlement continues occurring in the Indian government and the people as well. On January 26, 2021, tens of thousands of Indian farmers flooded into New Delhi to protest against agricultural reforms that allow large food companies to directly purchase crops at cheap prices [25]. In conclusion, Indian domestic social conflicts are more serious than Modi anticipated, which will continue developing as a weakness of India.

\section{CHINA NUCLEAR APPROACH}

China's People Liberation Army (PLA)'s the general approach to nuclear application remains unchanged over the years. The key elements for China's nuclear policy are defined as "No-First Use (NFU)" of nuclear weapons and minimum deterrence [26]. Since 1964, when China first became a nuclear state, nuclear weapons are not displayed in PLA's regular playbook. Two strategic plans will be analyzed in this section: minimum deterrence and security assurance to non-nuclear-weapon states.

The commitment of China to apply NFU policy to non-nuclear-weapon states is the logical development of China's minimum deterrence. Minimum deterrence is a theory in which a state possesses "no more nuclear weapons than is needed when an adversary is attacking" [27]. China has remained a small nuclear arsenal on many occasions. In the 2003 PLA National Defense White Paper, China claims "has always exercised utmost restraint on the development of nuclear weapons, and its nuclear arsenal is kept at the lowest level necessary for self-defense only." [28]. The definition of the lowest level of nuclear weapons is to make China survivable to first nuclear attack. In Chinese literature, the term "few but effective" is described as minimum deterrence by its meaning. The nuclear thinking that China echoes the characteristic of China's active defense strategy is similar to NFU ideology. Centrally, China's principle is to stop the war and safeguard global peace in its socialist military approach. From Beijing's perspective, many Western scholars do not read the NFU policy because they think that China would certainly be defeated in a conventional war [29]. On the contrary, Chinese scholars such as Li Bin explain China's nuclear minimum deterrence with a fair explanation. Li Ben said that China's policymakers understand that "China can be defended by relying on its conventional military power, size, people, and so on, and conventional strikes will not destroy the country" [29]. 
The significance of China's NFU policy upholds its longstanding nuclear taboo and reduces its risk of international nuclear war. This peaceful approach can protect China's global peacemaking figure and maintain stability during a crisis.

China's security assurance to non-nuclear-weapon states contributes to another unique factor of China's nuclear approach. China is carefully using its nuclear threats against non-nuclear-weapon states. Instead, China has joined UN Security Council and advocated all nuclear-weapon states to agree to a multilateral agreement under "which they would pledge not to use or threaten to use nuclear weapons against non-nuclearweapon states." [30]. Moreover, China has called for a proposal for the thorough destruction of nuclear weapons in 1963 [29]. All these efforts are reasonable to enact under a minimal deterrence ideology. In real politics, two factors allow China to practice its nuclear approach: Taiwan and the United States. Taiwan is China's prior security concern, and China is frustrated with U.S intervention in this case. However, no evidence exhibit that China considers nuclear weapons [28]. In the United States case, China displays a sensitive concern towards the U.S. Aegis Ballistic Missile Defense System (BMD) deployment and development. Particularly, BMD coverage to Taiwan would encourage Taiwan to take more proactive actions toward independence [28]. In addition, China has a further reason to worry about BMD's future cooperation in U.S and Japan alliance. It would become difficult to improve Sino-Japanese relations.

\section{CHINA NUCLEAR APPROACH}

China's People Liberation Army (PLA)'s the general approach to nuclear application remains unchanged over the years. The key elements for China's nuclear policy are defined as "No-First Use (NFU)" of nuclear weapons and minimum deterrence [26]. Since 1964, when China first became a nuclear state, nuclear weapons are not displayed in PLA's regular playbook. Two strategic plans will be analyzed in this section: minimum deterrence and security assurance to non-nuclear-weapon states.

The commitment of China to apply NFU policy to non-nuclear-weapon states is the logical development of China's minimum deterrence. Minimum deterrence is a theory in which a state possesses "no more nuclear weapons than is needed when an adversary is attacking" [27]. China has remained a small nuclear arsenal on many occasions. In the 2003 PLA National Defense White Paper, China claims "has always exercised utmost restraint on the development of nuclear weapons, and its nuclear arsenal is kept at the lowest level necessary for self-defense only." [28]. The definition of the lowest level of nuclear weapons is to make China survivable to first nuclear attack. In Chinese literature, the term "few but effective" is described as minimum deterrence by its meaning. The nuclear thinking that China echoes the characteristic of China's active defense strategy is similar to NFU ideology. Centrally, China's principle is to stop the war and safeguard global peace in its socialist military approach. From Beijing's perspective, many Western scholars do not read the NFU policy because they think that China would certainly be defeated in a conventional war [29]. On the contrary, Chinese scholars such as Li Bin explain China's nuclear minimum deterrence with a fair explanation. Li Ben said that China's policymakers understand that "China can be defended by relying on its conventional military power, size, people, and so on, and conventional strikes will not destroy the country" [29]. The significance of China's NFU policy upholds its longstanding nuclear taboo and reduces its risk of international nuclear war. This peaceful approach can protect China's global peacemaking figure and maintain stability during a crisis.

China's security assurance to non-nuclear-weapon states contributes to another unique factor of China's nuclear approach. China is carefully using its nuclear threats against non-nuclear-weapon states. Instead, China has joined UN Security Council and advocated all nuclear-weapon states to agree to a multilateral agreement under "which they would pledge not to use or threaten to use nuclear weapons against non-nuclearweapon states." [30]. Moreover, China has called for a proposal for the thorough destruction of nuclear weapons in 1963 [29]. All these efforts are reasonable to enact under a minimal deterrence ideology. In real politics, two factors allow China to practice its nuclear approach: Taiwan and the United States. Taiwan is China's prior security concern, and China is frustrated with U.S intervention in this case. However, no evidence exhibit that China considers nuclear weapons [28]. In the United States case, China displays a sensitive concern towards the U.S. Aegis Ballistic Missile Defense System (BMD) deployment and development. Particularly, BMD coverage to Taiwan would encourage Taiwan to take more proactive actions toward independence [28]. In addition, China has a further reason to worry about BMD's future cooperation in U.S and Japan alliance. It would become difficult to improve Sino-Japanese relations.

\section{INDIA NUCLEAR APPROACH}

Similar to China, India also has a long-history NFU policy of nuclear weapons. However, the doctrine of India NFU policy is constantly challenged inside the combination in recent years because Pakistan "do not rule out the first use of nuclear weapons in a conflict" [31]. Indian Defense Minister Ranjnath Sigh, under Modi's administration, tends to negate India's nuclear weapons NFU policy, as he stated: "Till today, our nuclear policy is 'no first use'. What happens in the future depends on the circumstances." [31]. Yet to come, India's nuclear 
thinking appears as chaotic as the debate of NFU policy continues. In this section, we are going to examine the argument over NFU.

The critics of NFU policy build up from India's conflict with Pakistan. Indian strategists and military officers criticize that NFU restricts New Delhi's options to Pakistan. Most importantly, India might "well use nuclear weapons first at a military crisis." [32]. The derivative thinking, along with nuclear weapons' first application, is to develop the capability for "nuclear preemption." [32]. Many Indian strategists fantasize the nuclear pre-emption and will place India in a winning position against Pakistan. However, this ideology lacks practice in reality. To make nuclear pre-emption credible, India's nuclear forces "needs a large modification which largely includes military preparation" before the nuclear operation [32]. One pre-requisite for quick launching is the nuclear warhead should attach with missiles. In contrast, most Indian nuclear warheads were "kept separate from the delivery vehicles" [32]. Certainly, it costs many to upgrade and build up its nuclear arsenal, while the significant budgetary pressure does not allow it. On the other hand, two serious dangers involve deploying missiles mated warheads. The greatest one is to accidentally launch due to false alarms that can endanger South Asia countries within short ranges [33]. Another danger is "the serious accidents involve nuclear weapons and delivery vehicles." [33].

On the other hand, NFU policy serves another purpose, namely a diplomatic tool. India's NFU policy is part of its "ongoing efforts at constructing itself as a 'moderate' and 'responsible' power" [34]. In this fashion, India has a legitimate reason to deflect international criticism of India's actions on nuclear testing. NFU diplomacy ultimately shapes India as a peaceful nuclear country and shields its aggressive plan to evolve nuclear power against Pakistan.

\section{CONCLUSION}

India and China have some similarities and differences when talking about the strategic approach in Eurasia. Similarly, both countries looked for a global cooperative opportunity to grow national prosperities and proposed an NFU policy as their primary nuclear approach. Differently, China has a clear and directive plan to build its international relationship by implementing the New Silk Road Project. China also has concerns about potential Indian strategic threat in Southeast Asia for its String of Pearl development. Despite India's BRI intervention, China has essentially achieved many of its 5-year goals on its foreign diplomacy. India, however, is less constructive on its grand strategy in Eurasia and placed itself into a dilemma in between China and the United States. Many Indian cross-country actions are taken in response to BRI, not solely because of New Delhi's interest. India is currently cooperating with Chinese strategic competitors despite India's interest to strengthen its national deterrent bargaining chip. By reaching military dealerships with the United States and Japan, India is showing its capability to respond evolution of PLA. However, India's internal political affairs require urgent solutions and long-term reformation since conflicts have cause domestic unrest. In conclusion, the Sino-Indian relationship will continue to develop into an unprecedented tension or perhaps reach a peaceful resolution in a future time.

\section{REFERENCES}

[1] Scobell, Andrew, Edmund Burke, Cortez Cooper, Sale Lilly, Chad Ohlandt, Eric Warner, and J.D. Williams. "China's Grand Strategy: Trends, Trajectories, and Long-Term Competition," 2020. https://doi.org/10.7249/rr2798.

[2] Leverett, Flynt, and Wu Bingbing. "The New Silk Road and China's Evolving Grand Strategy." The China Journal 77 (2017): 110-32. https://doi.org/10.1086/689684.

[3] Fallon, Theresa. "The New Silk Road: Xi Jinping's Grand Strategy for Eurasia." American Foreign Policy Interests 37, no. 3 (2015): 140-47. https://doi.org/10.1080/10803920.2015.1056682.

[4] Zhai, Huixia. “'One Belt One Road' Enhances China's Economic International Influence.” People's Pictorial, March 2019. http://www.rmhb.com.cn/zt/ydyl/201903/t2019030 8_800160443.html.

[5] Jaye , Nathan. "The Shanghai Free Trade Zone Continues Its Growth.” CFA Institute, September 17, 2018. https://www.cfainstitute.org/research/cfamagazine/2018/the-shanghai-free-trade-zonecontinues-its-growth.

[6] U.S. Department of State. U.S. Department of State. Accessed March 2021. https://history.state.gov/milestones/19611968/india-pakistanwar\#: :text=The $\% 201965 \% 20$ war $\% 20$ between $\% 2$ OIndia,state $\% 20$ of $\% 20 \mathrm{Jammu} \% 20$ and $\% 20 \mathrm{Kashmir}$ .\&text=Conflict $\% 20$ resumed $\% 20$ again $\% 20 \mathrm{in} \% 20 \mathrm{e}$ arly,border\%20between $\% 20$ the $\% 20$ two $\% 20$ nations.

[7] Khan, Zahid Ali. "China's Gwadar and India's Chahbahar: An Analysis of Sino-India Geo-strategic and Economic Competition." Strategic Studies 32/33 (2012): 79-101. Accessed March 9, 2021. doi: $10.2307 / 48527627$

[8] Sutton, H I. "China's New High-Security Compound In Pakistan May Indicate Naval Plans." Forbes. Forbes Magazine, June 2, 2020. 
[9] Sutton, H I. “China's New High-Security Compound In Pakistan May Indicate Naval Plans." Forbes. Forbes Magazine, June 2, 2020. https://www.forbes.com/sites/hisutton/2020/06/02/ chinas-new-high-security-compound-in-pakistanmay-indicate-naval-plans/?sh=22bc6ccd1020.

[10] Meredith, Sam. “As Russia and China Seek to Boost Their Global Influence, Analysts Warn Vaccine Diplomacy Is Here to Stay." CNBC. CNBC, February 17, 2021. https://www.cnbc.com/2021/02/17/covid-vaccinediplomacy-russia-china-seek-to-boost-globalinfluence.html.

[11] Bozhev, Ventsislav. "The Chinese String of Pearls or How Beijing Is Conquering the Sea." De Re Militari, August 26, 2019. https://drmjournal.org/2019/08/26/the-chinesestring-of-pearls-or-how-beijing-is-conquering-thesea/.

[12] Basrur, Rajesh. "The BRI and India's Grand Strategy." Strategic Analysis 43, no. 3 (2019): 18798.

https://doi.org/10.1080/09700161.2019.1598082.

[13] On the broad strategies of weak and strong states, see Michael Mandelbaum, The Fate of Nations: The Search for National Security in the Nineteenth and Twentieth Centuries, Cambridge University Press, New York, 1988.

[14] Khalid, Ijaz, Shaukat, and Azka Gul. "INDIAN RESPONSE TO CHINESE STRING OF PEARLS DOCTRINE." Global Political Review 2, no. 1 (2017): 27-35. https://doi.org/10.31703/gpr.2017(ii-i).03.

[15] Hughes, Lindsay. "Bypassing Pakistan: Afghanistan, India, Iran and Chabahar." Future Directions International, May 2016. https://www.futuredirections.org.au/publication/by passing-pakistan-afghanistan-india-iran-chabahar/.

[16] Berlin, Don. "The Rise of India and the Indian Ocean." Journal of the Indian Ocean Region 7, no. $1 \quad$ (2011): 1-31. https://doi.org/10.1080/19480881.2011.587329.

[17] Malik, J. Mohan. "Sino-Indian Rivalry in Myanmar: Implications for Regional Security." Contemporary Southeast Asia 16, no. 2 (1994): 137-56. https://doi.org/10.1355/cs16-2b.

[18] Brewster, David. "India's Strategic Partnership with Vietnam: The Search for a Diamond on the South China Sea?" Asian Security 5, no. 1 (2009): 24-44. https://doi.org/10.1080/14799850802611297
[19] Gale, Jesse Barker. "The Quadrilateral Security Dialogue and the Maritime Silk Road Initiative." The Quadrilateral Security Dialogue and the Maritime Silk Road Initiative | Center for Strategic and International Studies. Accessed March 10, 2021. https://www.csis.org/analysis/quadrilateralsecurity-dialogue-and-maritime-silk-road-initiative.

[20] Kemp, Geoffrey. The East Moves West: India, China, and Asia's Growing Presence in the Middle East. Washington, D.C: Brookings Institution Press, 2012.

[21] Roland Rajah, Alexandre Dayant, and Jonathan Pryke, Ocean of Debt? Belt and Road and Dept Diplomacy in the Pacific, Lowy Institute, October 21,2019 , pp. 4, 12, 14

[22] Jia, He. "In 2020, the "Belt and Road" import and export increase by $1 \%$ against the trend, and China's economic relevance is now regionally different." 21 Finance Accessed March 11, 2021. https://m.21jingji.com/article/20210116/44bf241eb 71762a60ca59bc57af1ca94.html.

[23] Breaking Down China's 2020 Defense Budget.” Breaking Down China's 2020 Defense Budget Center for Strategic and International Studies, March 22, 2021. https://www.csis.org/analysis/breaking-downchinas-2020-defense-

budget\#: :text=In\%202019\%2C\%20the\%20Chines e\%20government,to\%20have\%20been $\% 20 \% 24261$ $\%$ 20billion.

[24] "Who Has More Military Power, China or India?" Answers On, July 12, 2016. https://blogs.thomsonreuters.com/answerson/milita ry-power-china-vs-india/.

[25] Ashutosh, Varshney. "Ethnic and Religious Conflicts in India." Cultural Survival, September 1, 1983.

https://www.culturalsurvival.org/publications/cultu ral-survival-quarterly/ethnic-and-religiousconflicts-india.

[26] Pti. ''Delhi Chalo' Explainer: What the Farmers' Protest Is All About." The Economic Times. Economic Times, December 2, 2020. https://economictimes.indiatimes.com/news/politic s-and-nation/delhi-chalo-explainer-what-thefarmers-protest-is-allabout/articleshow/79460960.cms

[27] Heginbotham, Eric, Michael S. Chase, Jacob L. Heim, Bonny Lin, Mark Cozad, Lyle J. Morris, Christopher P. Twomey, Forrest E. Morgan, Michael Nixon, Cristina L. Garafola, and Samuel K. Berkowitz, China's Evolving Nuclear Deterrent: 
Major Drivers and Issues for the United States. Santa Monica, CA: RAND Corporation, 2017. https://www.rand.org/pubs/research_reports/RR16 28.html. Also available in print form.

[28] Blair, Dennis C. “CIA, Memorandum, Senate Select Committee on Intelligence (SSCI) Report, "U.S. Intelligence Analysis and the Oil Issue, 1973-1974', April 18, 1978, Top Secret, CREST." U.S. Intelligence on the Middle East, 1945-2009, n.d. https://doi.org/10.1163/9789004249028.umeob061 20.

[29] Kamp, Karl-Heinz. "Tong Zhao Li Bin (Hrsg.): Understanding Chinese Nuclear Thinking. 2016." SIRIUS - Zeitschrift für Strategische Analysen 1, no. 4 (2017): 403-4. https://doi.org/10.1515/sirius2017-0100.

[30] Yunzhu, Yao. "Chinese Nuclear Policy and the Future of Minimum Deterrence." Perspectives on Sino-American Strategic Nuclear Issues, 2008, 11124. https://doi.org/10.1057/9780230613164_8.

[31] Irman, Manuel. "China as Nuclear Power and Its UN Security Council Membership." GRIN. Accessed March 12, 2021. https://www.grin.com/document/181143.

[32] Dalton, Toby. "Much Ado About India's No-FirstUse Nuke Policy." Carnegie Endowment for International Peace. Accessed March 13, 2021. https://carnegieendowment.org/2019/09/26/muchado-about-india-s-no-first-use-nuke-policy-pub79952.

[33] Kristensen, Hans M., Matt Korda, Lauren J. Borja, M.V. Ramana, C. Rammanohar Reddy, Jens Heinrich, Dieter Fleck, et al. "India and the Policy of No First Use of Nuclear Weapons." Journal for Peace and Nuclear Disarmament. Accessed March 13, 2021. https://www.tandfonline.com/doi/citedby/10.1080/ 25751654.2018.1438737?scroll=top\&needAccess $=$ true.

[34] Sundaram, Kumar, and M. V. Ramana. "India and the Policy of No First Use of Nuclear Weapons." Journal for Peace and Nuclear Disarmament 1, no. $1 \quad$ (2018): 152-68. https://doi.org/10.1080/25751654.2018.1438737. 